\title{
Usage of Inulin, Lemon, Carrot and Pea Fibers as Prebiotic for Bifidobacterium Animalis Subsp. Lactis (BB-12)
}

\author{
Mutlu Buket Akin* and Musa Serdar Akin \\ Harran University Engineering Faculty Department of Food Engineering, Sanliurfa, Turkey
}

Submission: February 01, 2019 ; Published: February 08, 2019

*Corresponding author: Mutlu Buket Akin, Harran University Engineering Faculty Department of Food Engineering, Sanliurfa, Turkey

\begin{abstract}
Prebiotics, contain oligosaccharides, lignin, resistant starch, tannins and associated plant substances, stimulate growth of probiotic organisms. A lot of dietary fibers (DF) are used as prebiotics in foods. In this study, it was investigated if inulin, lemon, carrot and pea fibers have prebiotic effect or not on Bifidobacterium animalis subsp. lactis (Bifidobacterium BB-12). For this purpose skimmed milk was inoculated with Bifidobacterium BB-12 fortified with different DF, such as inulin, lemon, carrot and pea fibers. According to the results inulin and pea fiber stimulated Bifidobacterium BB-12, whereas lemon and carrot fibers had no prebiotic effect on Bifidobacterium BB-12. The highest prebiotic effect of inulin and pea fiber were found at a level of $2 \%$.
\end{abstract}

Keywords: Bifidobacterium BB-12; İnulin; Lemon; Carrot; Pea fiber

Abbrevations: DF: Dietary Fiber; BB-12: Bifidobacterium; MRS: Man Ragosa Sharpe; LSD: Least Significant Difference

\section{Introduction}

Prebiotics are defined as non digestible food ingredients that beneficially affect the host by selectively stimulating the growth and/or activity of one or more desired bacterial species in the colon, thus improving host health. Many oligosaccharides, are added to food as prebiotic, mainly to allow the preferential growth of probiotic organisms and called as prebiotics [1]. Dietary fiber (DF), which includes oligosaccharides, lignin, resistant starch, tannins and associated plant substances, is a remnant of the edible part of plant; it is analogous carbohydrates that are resistant to digestion and absorption in the human small intestine and undergo complete or partial fermentation in the human large intestine. It improves human health by the prevention, reduction and treatment of some diseases, such as diverticular and coronary heart diseases [2,3]. In this study it was investigated whether or not inulin, lemon, carrot and pea fibers have prebiotic effect on Bifidobacterium animalis subsp. lactis (Bifidobacterium BB-12).

\section{Materials and Methods}

Bifidobacterium BB-12 (Chr. Hansen, Turkey), inulin (Sigma, İstanbul), lemon, carrot and pea fibers (Arosel Food,İstanbul, Turkey) and skim milk powder (Pınar Dairy, İzmir, Turkey) were used as materials. Man Ragosa Sharpe (MRS) agar, nalidixic acid, neomycine sulphate, lithium chloride and paramomycine sulp hate obtained from Sigma chemicals (İstanbul, Turkey). All other reagents used were of analytical grade. 13 different reconstituted skim milk, with $12 \%$ dry matter, were prepared. For propagation of Bifidobacterium BB-12, each sterile reconstituted skim milk was supplemented with $0.50 \%, 1 \%$ and $2 \%$ inulin, lemon, carrot and pea fiber. Bifidobacterium BB-12 was grown until $\mathrm{pH}$ reach to 4.7 at $37^{\circ} \mathrm{C}$, using a $0.05 \%(\mathrm{w} / \mathrm{v})$ inoculum. The milks were kept cooled at $4^{\circ} \mathrm{C}$ until for enumeration. Bacterial counts were determined after $8 \mathrm{~h}$ fermentation. Fermented milks were decimally diluted in $100 \mathrm{~mL}$ sterile peptone water $(0.1 \%)$ and $1 \mathrm{~mL}$ aliquot dilutions were poured onto plates of the various selective and differential agars in triplicate. Bifidobacterium BB-12 were incubated anaerobically by using MRS-NNLP agar [4]. The plates were incubated at $37^{\circ} \mathrm{C}$ for $72 \mathrm{~h}$. Anaerobic conditions were created using Anaerocult A sochets (Merck). The results were expressed as colony-forming units per gram ( $\mathrm{cfu} \mathrm{g}^{-1}$ ) of sample. Statistical analyses were carried out using SPSS Version 5.0 (SPSS Inc. Chicago, IL, USA). Statistically different groups were determined by the LSD (Least Significant Difference) test [5].

\section{Results and Discussion}

Table 1 show the variations in Bifidobacterium BB-12 counts in reconstituted skim milk with and without DF. Bifidobacterium 
BB-12 counts were found to be in the range of 7.35-7.96 log cfu $\mathrm{g}^{-1}$, respectively. As seen, inulin and pea fiber had prebiotic effect for Bifidobacterium BB-12, whereas lemon fiber and carrot fiber did not have $(\mathrm{p}<0.05)$. Even if a slight increaring was found in the Bifidobacterium BB-12 counts in the skimmed milk fortified with lemon and carrot fibers, they were not significant $(p>0.05)$. Pea fiber led to slight increasing in the number of Bifidobacterium BB12 , while inulin caused the noticable increasing. Guler-Akın, Göncü, Akın \& Akın, \& Güler-Akın $[1,6,7]$ also reported that probiotics had the ability to ferment DFs.

Table 1: Viable counts of Bifidobacterium BB-12 in reconstituted skim milk with or without dieatary fiber addition (log cfu g-1).

\begin{tabular}{|c|c|c|c|c|}
\hline Milk with Fiber* (\%) & Inulin & Lemon Fiber & Carrot Fiber & Pea Fiber \\
\hline 0 & $7.43 \pm 0.12^{\mathrm{a} 2}$ & $7.43 \pm 0.12^{\mathrm{a} 1}$ & $7.43 \pm 0.12^{\mathrm{a} 1}$ & $7.43 \pm 0.12^{\mathrm{a} 2}$ \\
\hline 0.5 & $7.63 \pm 0.10^{\mathrm{a} 2}$ & $7.44 \pm 0.09^{\mathrm{a} 1}$ & $7.56 \pm 0.11^{\mathrm{a} 1}$ & $7.58 \pm 0.08^{\mathrm{a} 2}$ \\
\hline 1 & $7.95 \pm 0.06^{\mathrm{a} 1}$ & $7.52 \pm 0.22^{\mathrm{b} 1}$ & $7.52 \pm 0.08^{\mathrm{b} 1}$ & $7.85 \pm 0.09^{\mathrm{a} 1}$ \\
\hline 2 & $8.06 \pm 0.15^{\mathrm{a} 1}$ & $7.45 \pm 0.18^{\mathrm{b} 1}$ & $7.48 \pm 0.20^{\mathrm{b} 1}$ & $7.97 \pm 0.12^{\mathrm{a} 1}$ \\
\hline
\end{tabular}

*Different letters in the same line indicate significant differences among the samples depending on DF type and different numbers in the same column indicate significant differences among the samples depending on DF level $(p<0.05)$.

Fiber level affected the number of Bifidobacterium BB-12 statistically $(\mathrm{p}<0.05)$. The highest prebiotic effect of inulin and pea fiber were found at a level of $2 \%$. The higher inulin and pea fiber added, the more Bifidobacterium BB-12 obtained. The numbers of Bifidobacterium BB-12 decreased as lemon and carrot fiber increased $(\mathrm{p}<0.05)$ due to the possible decreasing of water activity of milk. As known DF is highly hygroscopic and had a high water binding capacity [8].

\section{Conclusion}

Results showed that lemon fiber and carrot fiber didn't affect of Bifidobacterium BB-12 counts and they had no prebiotic effect for Bifidobacterium BB-12. In contrast, inulin and pea fiber stimulated Bifidobacterium BB-12 and they could be used as potential prebiotic for Bifidobacterium BB-12. .

\section{References}

1. Güler-Akın MB, Göncü B, Akın MS (2018) Some Properties of Bio-Yogurt Enriched with Cellulose Fiber. Advances in Microbiology 8: 54-64.
2. Tomic N, Dojnov B, Miocinovic J, Tomasevic I, Simigic N, et al. (2017) Enrichment of Yoghurt with Insoluble Dietary Fiber from Triticale-A Sensory Perspective. LWT-Food Science and Technology 80: 59-66.

3. Göncü B, Çelikel A, Güler-Akın MS (2017) Akın Some properties of kefir enriched with apple and lemon fiber. Mljekarstvo, 67(3): 208-216.

4. Dave RI, Shah NP (1996) Evaluation of media for selective enumeration of Streptococcus thermophilus, Lactobacillus delbrueckii subsp. bulgaricus, L. acidophilus and Bifidobacteria. Journal of Dairy Science 79: 1529-1536.

5. Duzguneș O, Kesici T, Kavuncu O, Gurbuz F (1987) Researches and Practice Methods (Statistical Methods II). A. U. Agricultural Faculty Publishes: 1021, Ankara, pp. 381.

6. Güler-Akın MB, Ferliarslan İ, Akın MS (2016) Apricot Probiotic Drinking Yoghurt Supplied with Inulin and Oat Fiber. Advances in Microbiology 6: 999-1009.

7. Akın MS, Akın MB (2016) Elma Lifi ile Zenginlestirmenin Set Tipi Yogurtların Bazı Özelliklerine Etkisi. Harran Tarım ve Gıda Bilimleri Dergisi 20(2): 94-104.

8. Yu G, Bei J, Zhao J, Li Q Cheng C (2018) Modification of carrot (Daucus carota Linn. var. Sativa Hoffm.) pomace insoluble dietary fiber with complex enzyme method, ultrafine comminution, and high hydrostatic pressure. Food Chemistry 257: 333-340.

\begin{tabular}{l} 
Your next submission with Juniper Publishers \\
will reach you the below assets \\
- Quality Editorial service \\
- Swift Peer Review \\
- Reprints availability \\
- E-prints Service \\
- Manuscript Podcast for convenient understanding \\
- Global attainment for your research \\
- Manuscript accessibility in different formats \\
( Pdf, E-pub, Full Text, Audio) \\
- Unceasing customer service \\
Track the below URL for one-step submission \\
https://juniperpublishers.com/online-submission.php \\
\hline
\end{tabular}

